\title{
AMSTERDAMSCHE BANKIERS EN DE WEST IN DE 18e EEUW \\ DOOR
}

\author{
C. K. KESLER
}

$\mathrm{Na}$ den vrede van Utrecht in 1713 begint onze vaderlandsche geschiedenis een geheel anderen aanblik te vertoonen dan in voorafgaande tijdperken. Terwijl de geschiedenis van de 17e eeuw doet denken aan een bruisenden stroom, die opzijde dringt, wat hem in den weg komt, wekt die van de $18 \mathrm{e}$ de voorstelling op van dienzelfden stroom, die het vlakke land bereikt heeft en kalm voortvloeit, niet om de zee te bereiken, maar om in den Franschen tijd dood te loopen in een poel, waaruit geen uitweg mogelijk scheen. Meer dan een eeuw had de Republiek zich ingespannen, eerst om een plaats in te nemen te midden der mogendheden van Europa, daarna om die te behouden en om de veroverde positie te verbeteren. Haast boven hare krachten was die inspanning tijdens den negenjarigen en den Spaanschen successie-oorlog geweest; nu meende zij recht te hebben op rust, meende de nakomeling den tijd gekomen, om te genieten van wat de voorvaderen in harden strijd veroverd hadden. Bloei van den handel was en bleef de voornaamste zorg van den Nederlandschen koopman, weldra niet meer in de eerste plaats de goederenhandel waarmede wel geen fabelachtige, maar toch vrij zekere winsten te behalen waren, maar vooral de geldhandel, die sneller tot rijkdom, maar ook vaak tot geheelen ondergang voerde. In de 17 e eeuw waren de zonen en kleinzonen van de winkeliers van het begin der eeuw opgeklommen tot groothandelaars, die belangen hadden in Oost en West, hadden zich ook toegang weten te verschaffen tot de kringen der magistratuur. Zich daar 
te handhaven en een waardige plaats blijvend in te nemen, eischte rijkdom, maakte het ook wenschelijk, maatregelen te nemen, om te zorgen, dat de eenmaal ingenomen plaats in handel en bestuur voor de nakomelingschap behouden kon blijven. Vandaar de zucht tot speculatie, die den eenmaal zoo voorzichtigen koopman aangreep, de pracht en weelde der huizen en hofsteden, vandaar ook de contracten van correspondentie, waardoor het bekleeden van voordeelige ambten aan enkele families gewaarborgd bleef.

Het uitblijven van groote oorlogen gedurende het eerste gedeelte der eeuw schiep weldra een ongekenden toestand van welvaart in de Republiek en vooral te Amsterdam was een groote ruimte van geld, waarvoor op velerlei wijze belegging gezocht werd. Spoedig zag men Amsterdamsche bankiers optreden als geldschieters van vorsten en kwistig kapitalen te hunner beschikkking stellen. Ook voor de West, vooral voor Suriname was op ruime schaal geld ter beschikking en ook hier waren het vooral Amsterdamsche bankiers, die het verschaften. Amsterdam toch was het in de eerste plaats, dat belang had bij de zaken der Westindiche Compagnie en van de Geoctrooieerde Societeit. Iedere familie, die een of meer leden in de vroedschap had, had er ook wel, die of Bewindhebber der Compagnie of Directeur der Societeit waren, of was althans betrokken in de zaken, die door een der beide handelslichamen gedaan werden. Zoo werd feitelijk Suriname in de $18 \mathrm{e}$ eeuw een kolonie van Amsterdam en het werd dat vooral, toen in 1770 Burgemeesters ertoe overgingen, van Simon Boas, gemachtigde van den Baron van Aerssen, diens aandeel in de kolonie voor $f 700.000$ over te nemen. In 1751 nam de stad voor een bedrag vanf 30.000 deel in de hierna vermelde leening-Deutz ten behoeve van Surinaamsche plantages en in 1778 werd door Gecommitteerden der Stad in de Societeit van Suriname een voorstel aan Burgemeesters gedaan, haar nu rechtstreeks voor dit doel gelden te doen voorschieten. De zaken gingen in Suriname toen echter al minder goed, waarom het voorstel niet in de Vroedschap ter bespreking gebracht werd, 
want Burgemeesters vonden de zaak „van te verren uytsigt en veel te gevaerlyk om te worden g'amplecteert, hoezeer dat Burgem ${ }^{n}$ anderszins genegen waren en ook het intrest van deze stad was, om de Colonie in haer verlegenheyt te hulp te komen." De vrij gunstige omstandigheden, die in de West gedurende het midden van de $18 \mathrm{e}$ eeuw heerschten, maakten echter aanvankelijk het Amsterdansche kapitaal willig, daar belegging te zoeken. De inval van Cassard in 1712 met de onmiddellijke schade van de brandschatting en de veel erger vermeerdering van het aantal der Marrons die zij tengevolge had, had de kolonie op den rand van den ondergang gebracht. Kostbare boschtochten en militaire expedities werden daardoor telkens noodzakelijk. Nadat het echter gelukt was in de jaren 1749, '61 en '62 met verschillende groepen der wegloopers een soort vredesverdrag te sluiten, trad een tijdperk van binnenlandschen vrede in. Bovendien begon de koffiecultuur rijke baten op te leveren. Nadat tusschen de jaren 1711 en '13 de eerste proeven genomen waren, waarna in 1718 de eerste zending van boonen Directeuren der Societeit bereikte, bewoog de productie zich gedure nde bijna de geheele 18e eeuw in stijgende lijn, om in 1790 het maximum van 15 millioen pond te bereiken. Naast de koffie verschaften ook suiker, katoen en andere producten ruime voordeelen. Die gunstige stand van zaken, tijdelijke rust in het binnenland, gepaard met voordeelige oogstjaren, maakte, dat de plantage-eigenaars hun bezit belangrijk in waarde zagen stijgen en er met eenig vertrouwen toe konden overgaan, meer geld in de plantages te steken. Het daarvoor noodige kapitaal werd met kwistige hand verstrekt door Amsterdamsche bankiers, in de eerste plaats door den burgemeester Willem Gideon Deutz.

Deze was sedert 1719 hoofd der aanzienlijke firma Jean Deutz en Soon en W. G. Deutz, wier zaken in dit tijdperk gedirigeerd werden door Willem Gideon en zijn neef Jean Deutz van Assendelft. Het geslacht Deutz, dat een hoogst belangrijke rol gespeeld heeft in de geschiedenis van de haute finance van Amsterdam in de 18e eeuw, was vermoedelijk uit Keulen afkomstig en wel uit de voorstad, 
waaraan het zijn naam ontleende. Reeds in het laatst der 16 e eeuw kwamen daar leden der familie voor, die zitting hadden in den raad dier stad .In het laatst der 16e eeuw vestigde een hunner, Johann Deutz, zich als koopman in Oostindische waren te Amsterdam, waar hij huwde met Elizabeth Coymans, dochter van Balthasar Coymans, het hoofd der firma Balthasar Coymans en Broeders, die door hunne familie- en andere relaties met de firma's Trip en De Geer en o.a. door hunne bemoeiingen met den slavenhandel een vooraanstaande positie in de Amsterdamsche handelswereld innamen. Dat blijkt uit hunne rekeningen met de Wisselbank, dat blijkt ook uit de vorstelijke huizen, die de Coymans en de Deutzen op de Keizersen de Heerengracht voor zich lieten bouwen. Vooral het huis Coymans was beroemd, even beroemd haast als het vermaarde Trippenhuis. Het eerste, het bekende huis met de hoofden, vindt men in 1662 beschreven als „het overgroote, vermaarde huys van de Koymans, een huys gelijck een kerck int aanzien; hierin zijn heerlijke groote zalen met kostelijke schilderijen en andere vercierselen verciert". Het royale koopmanshuis op de Heerengracht, het huis met de marmeren kolommen, was door erfenis van moederszijde in het geslacht Deutz gekomen, en werd kort geleden door den Heer Van Aalst, President der Nederlandsche Handelmaatschappij aan de stad Amsterdam ten geschenke aangeboden, als officieele woning voor den burgemeester. Vorstelijke woningen waren dat, vorstelijk ook in dien zin, dat de bewoners in staat waren regeerende vorsten en vorstinnen binnen hare muren te ontvangen. Zoo logeerde in 1638 Amalia van Solms ten huize van Elias Trip, toen zij Maria de Medici bij haar bezoek aan Amsterdam vergezelde.

Willem Gideon Deutz kreeg, toen hij als hoofd der firma optrad, zaken te beheeren, waarvan de draden zich uitspanden over een belangrijk deel van Europa en breidde deze nog belangrijk uit door zijne bemoeiingen met de West. De grondslag voor de Europeesche bekendheid van de firma werd gelegd door den zoon van den stichter van den Amsterdamschen tak, Jean Deutz, die vrijwel de vol- 
ledige controle wist te verkrijgen over den handel in kwikzilver. Door zijne moeder Elizabeth Coymans met Amsterdamsche handelskringen in aanraking, verkreeg hij door zijn huwelijk met Geertruida Bicker nauwe relaties met de magistratuur. Geertruida Bicker toch was eene dochter van Mr. Jan Bicker, wiens andere dochter Wendela gehuwd was met den Raadpensionaris Johan de Witt. Deze had groot vertrouwen in zijn zwager Deutz en raadpleegde hem vaak in financieele aangelegenheden. Aan den anderen kant was deze verwantschap voor den bankier en handelsman Deutz weer voordeeliig. In 1664 toch sloot hij een contract met de Keizerlijke regeering, waarbij hij den titel verkreeg van Keizerlijk Factoor voor het kwikzilver. Daardoor werd het monopolie van den handel in dit artikel voor een groot deel te Amsterdam gevestigd, voor een ander deel ging het over Venetië. De kwikzilvermijnen van Idria in Stiermarken waren n.l. Oostenrijksch Rijksdomein en konden belangrijke baten opleveren, wanneer de handel in het product goed georganiseerd was, daaro.a. voor de goud- en zilverwinning in de Spaansche koloniën in Zuid-Amerika en Mexico veel vraag daarnaar was. Naast het huis Deutz werd een Venetiaansche firma als factoor aangesteld, terwijl een Weensch huis met de exploitatie der mijnen belast werd. Doordat Deutz van de Venetianen hun geheelen voorraad overnam, had hij tot het begin der 18e eeuw feitelijk den alleenhandel in kwikzilver in handen, wat belangrijke baten opleverde, o.a. doordat Jean Deutz door bemiddeling van Johan de Witt die voor deze transactie zijn invloed op den Spaanschen gezant aanwendde, in 1664 een opdracht kreeg voor de levering van 2000 vaatjes per jaar, ter waarde van $f 500.000$ voor de zilvermijnen in Mexico. De betrekkingen met de Keizerlijke regeering, op deze wijze begonnen, breidden zich voortdurend uit, vooral toen W. G. Deutz en zijn neef Mr. Jean Deutz van Assendelft de zaken der firma bestuurden. De Keizerlijke regeering, die o.a. door de oorlogen met de Turken met chronisch geldgebrek te kampen had, maakte gretig gebruik van de gelegenheid, die de relaties met het huis Deutz haar aanboden, om 
leeningen in Holland geplaatst te krijgen. Aanvankelijk werden als onderpand daarvoor de opbrengsten van de kwikzilvermijnen, later ook die van de kopermijnen in Hongarije gebruikt. Geleidelijk werden de voorgeschotnbedragen grooter en onder directie van W. G. Deutz werden leeningen van eenige millioenen gesloten o.a. op de inkomsten uit Bohemen en Silezië. De laatste daarvan kwam in 1736 tot stand door bemiddeling van den Utrechtschen bankier Tiberius Beeldsnijder Matroos. In 1741 werd echter Silezië door Frederik den Grooten veroverd, die uit den aard der zaak niet genegen was, de vordering van het huis Deutz te erkennen. Daardoor bleven $\frac{1}{8}$ van de Silezische leeningen en die op Bohemen onafgelost.

Dat was een zware slag voor het bankiershuis, waarbij nog kwamen tegenspoeden, ondervonden met leeningen ten behoeve van Suriname. De ruimte van geld in Amsterdam kwam deze kolonie zeer te stade. Geld was in Suriname steeds schaarsch geweest, reeds van het begin der Hollandsche periode af. Vooral sukkelde men er steeds mede, dat gemunt geld even snel wegvloeide, als het in omloop gebracht werd. Reeds de Gouverneur Heinsius had in het laatst der 17e eeuw noodmunten laten slaan, die de waarde hadden van 1, 2 of 4 pond suiker, tegen een stuiver per pond. Dit werd echter door de Staten-Generaal verboden en in den tijd van den Gouverneur Van Aerssen stonden reeds 24 stuivers Sur. gelijk met 20 stuivers Ned. De Gouverneur Crommelin nam ten slotte in 1761 zijn toevlucht tot het uitgeven van het z.g. kaartengeld en toen eenmaal de eerste stap op den weg van deze schijnbare versterking der koloniale geldmiddelen gezet was, werden in volgende jaren telkens grootere reeksen kaarten in omloop gebracht. Geld, in welken vorm dan ook, was dus uiterst welkom in Suriname. Daar was inmiddels in den loop der $18 \mathrm{e}$ eeuw , vergeleken bij den oorspronkelijken toestand, in het beheer der plantages een belangrijke wijziging gekomen. Deze waren voor het grootste gedeelte in handen van Nederlandsche, vooral Amsterdamsche eigenaars gekomen, die hun tropisch bezit door de z.g. administrateurs lieten besturen. Het bleek later, dat 
op de eerlijkheid van velen dezer lieden nogal wat was af te dingen en, dat de kapitalen, die nu naar Suriname begonnen te vloeien, vaak voor heel andere doeleinden aangewend werden, dan voor verbetering en uitbreiding der plantages. Vele daarvan waren reeds met hypotheek bezwaard en het nu ontvangen geld werd door de administrateurs gebruikt om zich uit de handen der particuliere geldschieters, die niet goedkoop waren, te verlossen. Indirect had dit natuurlijk de zake ten goede kunnen komen, als overigens de verkregen gelden juist beheerd waren geworden en Deutz, die zelf van zijne bemoeiingen betrekkelijk weinig voordeel had, beoogde een dergelijke conversie dan ook blijkbaar, want in de voorwaarden der negotitatie werd uitdrukkelijk vastgesteld dat „deze onderneminge geschiedde om de planters van haare zwaare interessen te ontheffen."

De eerste leening of negotiatie kwam door bemiddeling van W. G. Deutz in Mei 1753 tot stand, nadat gedurende de twee voorafgaande jaren de onderhandelingen met de stad Amsterdam en met de Geoctrooieerde Societeit erover gevoerd waren. Zij bedroeg $f 1.000 .000$, welk bedrag beschikbaar gesteld werd voor le hypotheken op plantages tegen $6 \%$ met als maximum bedrag voor iederen belanghebbende $\frac{5}{8}$ van de geschatte waarde van het onderpand. Zooals later zal blijken, werd van deze laatste bepaling ten nadeele van de geldschieters in het Moederland door de Directeuren van de negotiaties wel eens afgeweken. Verder werd al spoedig met de schatting der waarde van de plantages op ergerlijke wijze door de schatters of priseurs geknoeid en eindelijk werd het beschikbaar gestelde geld veelal niet gebruikt ten nutte der plantages, maar door de administrateurs aan allerlei weelde verspild. Het aanvankelijk gefourneerde kapitaal van $f 1.000 .000$ werd inmiddels, daar deze misbruijken eerst later aan het licht kwamen, geleidelijk opgevoerd tot het viervoudige van dat bedrag. Deze financieele operaties, in verband met de ondervonden tegenslagen met de Oostenrijksche leeningen, gingen ten slotte de krachten van het huis Deutz te boven. Bij den dood van W. G. Deutz in 1757 bleken zijne 
zaken „in geëmbrouilleerde Staat” te verkeeren, ofschoon hij bij zijn leven geschat werd op een voor dien tijd kolossaal inkomen van $f 22$ à 24.000 per jaar. Tot den desolaten boedel behoorde een vordering op Surinaamsche plantages van $f 900.000$. Deze vordering werd voor $f 400.000$ overgenomen door de Amsterdamsche firma Jan en Theodoor van Marselis.

Daardoor werden de belangen van het huis Marselis in de West, die toch reeds aanzienlijk waren, nog uitgebreid. De oudste firmant, Jan was door zijn huwelijk met Maria Rijnbrandina Agnes Buteux belanghebbende geworden in de plantage Aurora met 126 slaven, die deze geërfd had van haar vader Dr. P. Buteux. In 1771 werd deze plantage geveild en voor $f 200.000$ opgehouden. Bovendien was de firma Van Marselis in 1746 aangesteld als Representante van Z.H. den Prins-Erfstadhouder Willem IV als opperbevelhebber en Gouverneur-Generaal der W.I. C. Door de overneming der vordering op Surinaamsche plantages werd de firma nu de voornaamste importeur in Amsterdam van Westindische suiker en koffie, evenals het Huis Deutz dat vroeger geweest was. De beide firmanten waren in dien tijd de bovengenoemde Jan en zijn jongere broeder Dirk, die zijn naam verfranscht had tot Theodoor en "door de bank de Franse heer Marselis genaampt werd". Voorschieten van geld op vaste goederen was reeds een oud bedrijf der firma geweest. Een eeuw vroeger toch, reeds in 1657, had de koopman Gabriel Marselis belangrijke bedragen aan Christiaan IV van Denemarken voorgeschoten, als hypotheek op landgoederen in Kallandsborg, een voortzetting trouwens van vroegere relaties met den Deenschen koning. De firma die oorspronkelijk in Hamburg gevestigd was en daaroptrad als Commissaris en Resident van den koning van Denemarken, had ook een vertakking in Rusland, te Toela gevestigd. Dit Russische filiaal leverde in 1644 ijzer en geschut aan Denemarken, evenals Louis de Geer dat aan Zweden deed. Zelfs had de firma zich in 1638 met oogluikende toestemming van het Staatsbestuur bezig gehouden met levering van kruit aan de Spanjaarden in de 
Zuidelijke Nederlanden. Wegens de bewezen diensten was het geslacht door den Deenschen koning in 1673 in den adelstand verheven en voerde sedert het adellijke Van voor den familienaam.

De overgenomen vordering op de Surinaamsche plantages gaf de firma nu aanleiding te trachten, den financieelen toestand daar te verbeteren. In 1764 werd, ten einde in het vervolg knoeierijen met de schatting van de waarde van plantages en huizen te voorkomen, van het Hof van Politie een nieuwe instructie voor de priseurs verkregen en debiteuren, die achterstallig waren in het betalen van rente en aflossing, zagen hunne plantages onder sequestratie gesteld. Voorloopig was echter de willigheid van het Amsterdamsche kapitaal, om zich met Suriname in te laten, voorbij. Later werden wel onder andere voorwaarden de negotiaties nog uitgebreid, maar na den dood van W. G. Deutz was het tijdelijk met den goudstroom uit. Het sluiten van den vrede na het einde van den zevenjarigen oorlog maakte een algemeene afrekening van onderlinge vorderingen noodzakelijk. De belangrijke speculatie in wissels gedurende voorafgaande jaren, de uitgifte van veel papiergeld zonder voldoende dekking in verschillende landen en het verzwakken van de munt o.a. in Pruisen en $Z$ weden, al deze oorzaken werkten samen om in 1763 de beruchte crisis op de Amsterdamsche beurs te veroorzaken. Door de groote vraag waren er wissels verhandeld tegen 15 maal het nominale bedrag; deze moesten nu afgerekend worden en het eerste gevolg daarvan en van andere oorzaken was het faillissement van het bankiershuis. De Neuville met een passief vanf3.000.000. In zijn val sleepte dit vijftig andere firma's mede. De gevolgen van dien krach bleven voor Suriname niet uit. Het geld verdween daar even spoedig, als het gekomen was en wie nog wat hadden weten te redden, trachtte zich schadeloos te stellen door het uitleenen aan minder begunstigden tegen woekkerrente. In 1761 reeds was weliswaar het nemen van een hoogere rente dan $8 \%$ verboden, maar er waren altijd wel middelen te vinden, om een dergelijke bepaling te ontduiken. 
Nadat de Amsterdamsche beurs de gevolgen van de crisis van 1763 te boven gekomen was en gedurende eenige jaren meer normale toestanden begonnen te heerschen, hernieuwde zich, zij het ook in mindere mate, dan te voren, de belangstelling van Amsterdamsche bankiers voor de West. De firma Jan en Theodoor van Marselis breidde geleidelijk het bedrag der gesloten negotiatiën uit en belangrijke bedragen werden onder hare directie voorgeschoten op plantages en andere vaste goederen. In de jaren 1772 en '73 verstrekte zij o.a. hypotheken op de plantage Hamburg, Clevia, de Goede Verwachting, Klein Pérou, Vlaardingen, Catharinenburg, Onverwagt en op een twaalftal woonhuizen te Paramaribo. De hypotheken van het jaar 1773 bedroegen te zamen $f 800.000$ à $5 \frac{1}{2} \%$. Ook andere bankiers begonnen zich weldra met dergelijke zaken bezig te houden, b.v. de firma Harman en de Poll \& Co, Adolf Jan Heshuysen \& Co te Haarlem en Amsterdam en het huis Hope \& Co. te Amsterdam. Voor een goed deel is de oorzaak van de hernieuwde belangstelling dezer bankiers in de West, in het bijzonder voor Suriname, weer te vinden in hunne betrekkingen tot de W.I.C. of de Geoctrooieerde Societeit. Zoo was b.v. Mr. Harman Hendrik van de Poll in 1727 Directeur der Societeit, terwijl zijn kleinzoon, Mr. G. W. van de Poll van 1786-'88 de betrekking van Secretaris der Kolonie Suriname te Amsterdam bekleedde. In 1749 stichtte de zoon van den bovengenoemden Mr. H. H. van de Poll het bankiershuis Harman van de Poll \& Co., dat in de jaren 1765, '69 en '87 belangrijke sommen ten dienste der koloniën Suriname en Berbice voorschoot. In dien tijd werden dergelijke negotiatiën vaak door letters aangeduid; die van 1765 en 1769 b.v. waren respectievelijk bekend, als Lett. A. en Lett. C. Veel genoegen en voordeel beleefde ook dit huis niet aan deze financieele operatiën: zelfs had een der firmanten er den bijnaam, Letter A., waaronder hij op de beurs bekend was, aan te danken. Dit was de kleinzoon van Mr. H. H. van de Poll, die o.a. in 1758 als woordvoerder optrad van een deputatie van 41 kooplieden uit Dordrecht, Rotterdam, Amsterdam en het Noorderkwar- 
tier, die bij de Prinses-Gouvernante aandrongen op betere bescherming der koopvaarders tegen de Engelschen. Omtrent zijn bijnaam Letter A verhaalt Mr. Jacob van Lennep: „Hij was Directeur van zekere negotiatie, die den naam van Letter A dragende, gevestigd was op plantages in Suriname en afgegeven 1 Maart 1766. Ongelukkig was de zaak voor de aandeelhouders alles behalve voordeelig, wat aanleiding gaf, dat zij uit wrevel den bedoelden bijnaam aan den Directeur gaven." De hier bedoelde negotiatie was groot $f 2.417 .000$ à $6 \%$ en werd verstrekt op 21 plantages in Suriname te zamen geschat op een waarde van $f$ 4.024.756. Wie geld wilde hebben, had zich te vervoegen bij het Hof van Politie, dat eerst de bezittingen der aanvragers deed schatten, waarna een zeker bedrag ter beschikking gesteld werd. De geldschieter kreeg daarvan $2 \frac{1}{2} \%$ provisie, terwijl de planters de verplichting op zich namen hunne producten uitsluitend aan hem te consigneeren. Gouverneur en Raden kregen het recht, zoo de planters hunne producten elders ten verkoop aanboden, deze in beslag te nemen ten behoeve van het fonds. In 1774 bracht de verkoop van koffie, suiker, katoen en cacao op $f 100.285$, doch in het volgende jaar belangrijk minder door de daling der prijzen van de producten, terwijl bovendien in hetzelfde jaar de plantages Montpellier en Montauban door de Marrons werden geplunderd. Hierbij kwam nog een schrale koffieoogst in 1775. Hoewel het regel was, dat op plantages niet meer, dan $\frac{5}{8}$ der geschatte waarde als hypotheek gegeven werd, (soms werd voor oude gronden slechts de helft gegeven) hadden Directeuren der negotiatie in de gunstige jaren dit bedrag soms overschreden en waren tot $\frac{2}{3}$ der geschatte waarde gegaan. Door bepaalde kunstgrepen in de boekhouding wisten zij nu zichzelf voor schade te vrijwaren, door haar op de aandeelhouders af te wentelen, wat onder deze een te verklaren ontstemming verwekte. Toch genoot het huis Van de Poll in handelskringen een groot vertrouwen, wat o.a. blijkt uit de omstandigheid, dat dezelfde Mr. Jan van de Poll, waarvan hierboven sprake was, met Adriaan Hope en Jacques Teysset in 1773 
belast werd met de liquidatie van het faillissement van het huis Clifford \& Zoon.

Faillissementen van vooraanstaande huizen met al de treurige gevolgen, die deze nasleepten, kwamen in die tijden nogal eens voor en naast andere oorzaken, waren vaak speculaties in Westindische waarden daarvan de schuld. Deze laatste waren soms aan vrij sterke schommelingen op de beurs onderhevig en geruchten omtrent plundering van plantages door de Marrons werden door speculanten wel opzettelijk verspreid om, wanneer het hun wenschelijk leek, de waarde der aandeelen in eene negotiatie te doen dalen. Daarbij werd door de bezitters daarvan soms wel $40 \%$ verlies geleden. Zoo ging in 1781 de firma Jan en Christiaan van Tarelink, waarvan een der firmanten deel genomen had in een Surinaamsche negotiatie failliet en vindt men in het Grootmemoriaal van Amsterdam aangeteekend ,dat zij beiden van nu af aan en voor altoos renuntieeren van hunne ambten en bedieningen, die zij in de stad bekleeden en diensvolgens verzogt (hebben), dat hunne naamen voortaan uit het Heeren Boekje en uit de Lijst der Regeeringe mogte uytgelaten worden, hetwelk door H. G. E. A. aan dezelve is geaccordeert." Ook het huis Barth. van den Santheuvel \& Zoon te Amsterdam geraakte door de Westindische zaken in moeilijkheden. De stichter daarvan, was afkomstig uit Dordrecht, waar hij handelde op de West en de Levant. In 1718 vestigde hij zich te Amsterdam, huwde met Gosewina Maria Momber, werd in 1724 benoemd tot Directeur van den Levantschen handel en hield zich in zijn nieuwe woonplaats vooral met bankierszaken bezig, o.a. met negotiatiën ten dienste van plantages in Suriname, Essequebo en Demerara. Hierop zullen de zaken van zijn schoonvader wel van invloeed geweest zijn; deze toch Hendrik Momber was een bekend makelaar in Oost- en Westindische actiën te Amsterdam. In 1759 werd een zoon, Barth. van den Santheuvel Jr. in de zaken opgenomen en deze werd, evenals zijn vader geweest was, in 1763 tot Directeur van den Levantschen handel benoemd. Het is bekend, dat in het laatst der $18 \mathrm{e}$ eeuw de pers zich met 
staatkundige en financieele aangelegenheden begon te bemoeien en zich daarbij nogal eens op persoonlijk terrein begaf, waarbij zij voor onware voorstellingen van zaken niet al te bevreesd was. Vooral in tijden van heftige politieke troebelen regende het schotschriften, o.a. in 1787; toen door den inval der Pruisen de Oranjepartij voor korten tijd weer zegevierde, de patriottische regenten bij menigte van het kussen raakten en door aanhangers der tegenpartij vervangen werden. Een dezer was de Amsterdamsche koopman Everard Adriaan van Muiden, die met Christiaan van Tarelink commissaris van eene in 1776 tot standgekomen plantageleening geweest was. Van Muiden was mismaakt en schijnt niet onberispelijk van gedrag geweest te zijn. Desniettegenstaande werd hij bij de omkeering in 1787 door Prins Willem V aangesteld als Bewindhebber der O.I.C. In pamphletten uit die dagen wordt op onbarmhartige wijze zijn doopceel gelicht en komt hij voor onder den vriendelijken bijnaam van „de kurketrekker.” De firma Van den Santheuvel ondervond de welwillendheid van de pers reeds in 1740. In de Leidsche Courant verscheen toen n.l. eene oproeping van schuldeischers in den faillieten boedel van de Wed. Kemena en Van den Santheuvel, de naam, waaronder de firma destijds handelde, om zich voor den len September van dat jaar te Amsterdam aan te melden. Van den Santheuvel, die geenszins failliet was, loofde een premie van $f$ 3000.- uit om den steller der oproeping te ontdekken en aan de justitie over te leveren. Het schijnt echter, dat deze niet opgespoord werd; hoe het zij, zeker is het, dat de zaken der firma toen nog niet wankel stonden, want in 1746 verrekende zij nog een bedrag van $f 1.110 .000$ met de Amsterdamsche Wisselbank. De relaties met de West brachten de zaken echter in de war. In de jaren 1770 en 1775 schoot het huis Van den Santheuvel \& Zoon belangrijke sommen voor op plantages in Suriname, o. a. op Mariënburg en in 1772 f 500.000 op gronden in Essequebo en Demerara. Deze laatste hypotheken vooral leverden schade op; rente en aflossing bleven uit en daarom verzocht Barth. van den Santheuvel Jr. in 1775 aan de Sta- 
ten-Generaal „sauf-conduit" om hem in staat te stellen, orde op de zaken te gaan stellen en zich ertegen te beveiligen, dat hij in de West in moeilijkheden geraakte. Zijn crediteuren verzetten zich er echter tegen, dat hij zich uit de Republiek verwijderde en dienden een contra-request in, met verzoek, het gevraagde vrijgeleide te weigeren. Na tusschenkomst van Burgemeesters van Amsterdam, werd dit echter toch verleend en in 1777 vestigde Van den Santheuvel zich in de West ,ter verrigting zijner affaires". Hoewel hij zijn burgerschap van Amsterdam had wenschen te behouden, werd dit hem door Burgemeesters na zijne vestiging in de tropen opgezegd.

Behalve de genoemde interesseerden zich in dien tijd nog verschillende andere bankiershuizen voor de West, niet alleen voor de Nederlandsche, maar ook voor de Deensche en Engelsche bezittingen. Hierboven werd reeds genoemd het huis Adolf Jan Heshuysen \& Co., dat te Haarlem gevestigd was en een bijkantoor te Amsterdam had. In 1776 waren de firmanten Adolf Jan, Frans Jacob, en Floris Visscher Heshuysen. De tweede begaf zich voor de behartiging der zaken persoonlijk naar de West en stierf op zijn terugreis van Curaçao in 1792 . De eerstgenoemde, het eigenlijke hoofd der firma, was in 1764 gehuwd met Lucia Hope, die behoorde tot de schatrijke familie, waarvan verschillende leden tot de Westindische koloniën in betrekking stonden. Het bankiershuis Hope \& Co., dat een tijdlang de eerste plaats in de Europeesche financieele wereld innam, waarvan het in den Franschen tijd door Rothschild verdrongen werd, verschafte vooral geld ten dienste van planters op de Deensche eilanden, later ook op enkele Engelsche. Het eerste kwam voort uit de betrekkingen, die sedert 1752 tusschen de firma en de Courantbank te Kopenhagen bestonden, het laatste vindt een gereede verklaring in den oorsprong der familie, die van Engelsche afkomst was.

Hoewel die geen Amsterdammer en ook geen bankier was, moge hier tevens vermeld worden als geldschieter voor Westindische plantages de Middelburgsche burgemeester Mr. Kornelis van den Helm Boddaert die o.a. in 
de jaren 1768 en 1772 negotiatiën ten behoeve van plantages in de koloniën Essequebo en Demerary tot stand bracht. Deze behoorde tot de Middelburgsche koopliedenen regenten-familie Boddaert, waarvan verschillende leden bewindhebbers van de Oost- en Westindische Compagnieën geweest zijn en had bij zijn familienaam dien van zijne grootmoeder Cornelia van den Helm aangenomen. Terwijl men in Amsterdam vooral belangstelling voor Suriname toonde, had men in Zeeland in de eerste plaats oog voor Essequebo, Demerary en Berbice. Zelfs eischten de Zeeuwen op grond van eerste vestiging aldaar voor zich het recht van alleenhandel op die koloniën op, wat hun echter steeds door den Raad van X bestreden werd en tot eindelooze geschillen aanleiding gaf. Deze werden in 1771 door een uitspraak van den Stadhouder beslecht en in hetzelfde jaar werd in Zeeland opgericht de Societeit ter Navigatie op Essequebo, waarvan Van den Helm Boddaert president was. Deze vennootschap kon echter op weinig succes bogen. Ook het tot standkomen der negotiatiën liep niet zoo vlot van stapel. Wel nam de stad Middelburg in die van 1768 deel voor een bedrag van $f 50.000$, maar het gelukte niet, het geheele kapitaal van $f 300.000$ alleen in Zeeland geplaatst te krijgen. Daarom werd de hulp van een Haagsch en van een Utrechtsch bankiershuis ingeroepen en ook van de firma Heshuysen te Amsterdam en Haarlem. Zonder medewerking van Amsterdammers kon men het blijkbaar in zulke zaken niet stellen.

Het gezamenlijk bedrag der negotiatiën wordt verschillend opgegeven, wat niet te verwonderen is, daar volstrekt niet alles omtrent die zaken bekend is. Zeer aanzienlijk is het echter zeer zeker geweest, want er zijn er meer dan honderd bekend en wellicht zijn er meer gesloten. Eenig denkbeeld omtrent de grootte van het bedrag verkrijgt men, als men nagaat, dat de voornaamste bankiershuizen in Holland, Zeeland en Utrecht erin betrokken waren. Telkens komt men in de stukken, díe op negotiatiën betrekking hebben, namen tegen, bekend in de Amsterdamsche en de Surinaamsche geschiedenis. Van 
de laatste moge b.v. genoemd worden Salomon Duplessis, die in 1777 als commissaris voor een leening optrad, ten laste van Frederik Cornelis Stolkert. Ook een enkele Rotterdammer komt onder de geldschieters voor, n.1. Ferrand Whaley Hudig, wiens Westindische zaken in een vroegeren jaargang van dit tijdschrift naar aanleiding van een geschrift van zijn kleinzoon door Dr. Benjamins besproken werden. De Raadpensionaris Van de Spiegel berekende in 1782 het opgespaarde kapitaal in de Republiek op een milliard, waarvan volgens zijne berekening 140 millioen geplaatst was in leeningen op Westindische plantages; andere opgaven spreken van 50 à 60 millioen alleen voor Suriname. Maar de ervaringen van Nederlandsche financiers met de West waren van zoodanigen aard geweest, dat na het herstel van onze onafhankelijkheid, in weerwil van de pogingen van Koning Willem I tot opheffing van de noodlijdende koloniën in Amerika, de belangstelling zich voor meer dan een eeuw bijna uitsluitend op de Oost richtte. Wat van de 18e-eeuwsche financieele operaties overbleef, waren vrijwel waardelooze obligaties, die evenals Fransche assignaten en dergelijke stukken nog wel in sommige families onder de vergeelde papieren bewaard worden. Zeer lang heeft de afwikkeling van vele der zaken geduurd. Eigenaardig is het wel, dat de oudst bekende leening, die van Deutz, het langst in stand gebleven is. In 1866 werden daarvan de oorspronkelijke stukken à $f 26$.- ingetrokken, waarbij een bewijs werd uitgereikt, luidende: „Houder dezes is geregtigd tot $\frac{\text { een }}{2409}$ aandeel in het saldo van hetgeen bij de finale likwidatie van het fonds van eigendom, gesproten uit de negotiatie in den jare 1752 opgerigt door wijlen W. G. Deutz zal blijken te bestaan." Deze bewijzen waren gedagteekend Amsterdam, den 31sten Mei 1866 en droegen de handteekening J. en Th. van Marselis, Directeuren. In 1904 was dat saldo nog niet verdeeld en bedroeg toen ongeveer $f 12.000$.

Onwillekeurig komt in deze dagen de vraag op, of thans in de 20ste eeuw na een eeuw van onthouding, het Nederlandsche kapitaal zich opnieuw voor de West zal 
gaan interesseeren en den draad der historie weer zal gaan voortspinnen, die op het einde van de $18 \mathrm{e}$ werd losgelaten. En voor Nederland, dat op koloniaal gebied een reputatie te verliezen heeft, èn voor Suriname in het bijzonder, waar nog zooveel tot stand gebracht zou kunnen worden, is dat ten zeerste te hopen.

Voor Nederland in de eerste plaats. Want, was Suriname sedert 1770 vooral een Amsterdamsche, bij het herstel onzer onafhankelijkheid werd het een Nederlandsche kolonie. En sedert de laatste grondwetsherziening is zelfs het woord kolonie verdwenen en zijn Oost en West inherente gebiedsdeelen van Grooter-Nederland geworden. Voor het weder opvatten van de draad der historie, voor het opnieuw toonen van belangstelling voor het wonderschoone, maar zoo diep-verwaarloosde Suriname schijnt thans het psychologische moment gekomen. Daar ginds zetelt een Gouverneur, verre nazaat van den 17e eeuwschen empire-builder Cornelis van Aerssen van Sommelsdijck, die niet aflaat van pogingen, om Suriname uit zijn verval op te heffen. Hier te lande worden in woord en gegeschrift die pogingen met nadruk ondersteund.

Met betrekking tot de Oost schreef Coen reeds in de 17e eeuw zijn overbekende woorden: „Dispereert niet, want daer can in Indien wat groots verricht worden". Dat kon, als men maar zijn raad volgde door te zenden ,,sonder ophouden meenichte van volck, schepen, gelt en alderley nootlyckheden." En krachtig wees hij op onbekendheid met Indië en op verkeerd inzicht in het moederland als de voornaamste vijanden van vooruitgang der op te bouwen kolonie door te klagen over „d'onwetendheyt en onbedachtheyt, die onder UE. regneert en de verstandigen overstempt". Hij had hetzelfde voor Suriname in onze eeuw kunnen schrijven. Ook daar kan wat groots verricht worden, niet te eeniger tijd, niet over tientallen van jaren, maar nu en in de allernaaste toekomst. De Amerikaansche adverteerder voegt aan zijne annonce nog al eens toe de aansporing: „Do it now”. Dat zegt de Ondernemersraad in het bekende rapport eveneens. Niet morgen, niet over 25 jaar, maar nu is het tijd met het verleden te bre- 
ken en Suriname weer opnieuw op te bouwen. Nu nog kan Indië uit zijn bevolkingsoverschot werkkrachten verschaffen, nu schijnt het Indische kapitaal genegen te doen wat in de 18e eeuw het Amsterdamsche trachtte te verrichten.

Wie weet tegenwoordig nog wat van Suriname in Amsterdam? Hier in Amsterdam waar, in weerwil van geleden verliezen toch voor een deel de prachtige koopmanshuizen op Keizers- en Heerengracht opgebouwd zijn met het goud uit de West. Wie weet thans hier, dat daarginds in den bodem nog schatten liggen, die aan het licht gebracht kunnen worden, als kapitaal en arbeid zich daarvoor wilden inspannen. „D'onwetendheyt en onbedachtheyt”, waaronder in Coens tijd Indië gebukt ging, drukken nog steeds zwaar op Suriname.

„Heeft Suriname een toekomst?" vroeg op 10 December 1926 Mr. J. W. Eekhout, Oud-Gouvernements-Secretaris, in zijn rede voor het Indisch Genootschap te 's-Gravenhage. Een verleden heeft het zeker, een verleden van tegenslagen en mislukte proefnemingen, een verleden, waarmede gebroken dient te worden, om de toekomst beter te doen zijn. Dat verleden werd o.a. beheerscht door overwegingen van meer of minder rentabiliteit der door Amsterdamsche bankiers verschafte kapitalen; in het verleden bleef daardoor de belangstelling voor Suriname opgesloten binnen de muren van Amsterdamsche kantoren. De toekomst moge brengen een algemeene belangstelling zich uitende in daden niet alleen hier te Amsterdam, maar in geheel Nederland aan deze en aan gene zijde van den Oceaan.

December 1926.

De gegevens vòor dit opstel zijn voornamelijk ontleend aan:

G. J. Fabius. Het Bankwezen in Nederl. West-Indië.

- Instituut voor Economische Geschriften. II.

Johan E. Elias. De Vroedschap van Amsterdam, 15781795.

Dr.W.W.van der Meulen.WestindischePlantageleeningen.

- Bijdragen en Mededeelingen van het Historisch Genootschap. 25e deel. 